\title{
A model of teaching english to students of technical universities based on media technologies
}

\section{Madina GANIHANOVA ${ }^{1}$ \\ Tashkent State Technical University named after Islam Karimov}

\begin{tabular}{l} 
ARTICLE INFO \\
\hline Article history: \\
Received October 2021 \\
Received in revised form \\
15 October 2021 \\
Accepted 20 November 2021 \\
Available online \\
15 December 2021
\end{tabular}

\section{Keywords:}

Multimedia,

information,

Media education,

pedagogical level,

methodological level,

Projects Method.

\begin{abstract}
The word "multimedia" has become popular since the 90s of the last century. Multimedia is a multicomponent and multisphere environment that allows the use of text, graphics, video and animation. This includes - different planes of the real and virtual world. Multimedia is a rich arsenal of ways to illustrate the phenomenon under study in its various aspects.
\end{abstract}

2181-1415/C 2021 in Science LLC.

DOI: https://doi.org/10.47689/2181-1415-vol2-iss11/S-pp210-214

This is an open access article under the Attribution 4.0 International (CC BY 4.0) license (https://creativecommons.org/licenses/by/4.0/deed.ru)

\section{Texnika oliy o'quv yurtlari talabalariga ingliz tilini media- texnologiyalar asosida o'qitish modeli}

\author{
Kalit so'zlar: \\ multimedia, \\ axborot, \\ mediata'lim, \\ pedagogik daraja, \\ uslubiy daraja, \\ loyihalar usuli.
}

\section{ANNOTATSIYA}

"Multimedia" so'zi o'tgan asrning 90-yillaridan boshlab mashhur bo'ldi. Multimedia ko'p komponentli muhit bo'lib, matn, grafik, video va animatsiyadan foydalanish imkonini beradi. Multimedia o'rganilayotgan hodisani tasvirlash usullarining eng boy arsenalidir.

\footnotetext{
1 Teacher of the Foreign Languages Department, Named after Islam Karimov Tashkent State Technical University. Tashkent, Uzbekistan. E-mail: mbganikhanova@gmail.com.
} 


\section{Модель обучения английскому студентов технических вузов на основе медиа-технологий}

\author{
Ключевые слова: \\ Мультимедиа, \\ информация, \\ медиаобразование, \\ педагогический уровень, \\ методический уровень, \\ Метод проектов.
}

\begin{abstract}
АННОТАЦИЯ
Слово «мультимедиа» стало популярным с 90-х годов прошлого века. Мультимедиа - это многокомпонентная и многосферная среда, позволяющая использовать текст, графику, видео и анимацию. Это включает в себя - различные плоскости реального и виртуального мира. Мультимедиа богатейший арсенал способов проиллюстрировать изучаемое явление в различных его аспе.
\end{abstract}

\section{INTRODUCTION}

The computer, which has penetrated the field of education, is a universal means of information processing. "Multimedia" means the ability to work with information in various forms, and not only in digital form, as with conventional computers. The versatility of a computer lies in the fact that, on the one hand, it alone is able to process information of different types (multimedia information), on the other hand, one and the same computer is able to perform a whole range of operations with information of one type. Thanks to this, the computer, in conjunction with the appropriate set of peripheral devices, is able to provide the performance of all the functions of technical multimedia teaching aids.

MATERIALS AND METHODS: The use of media in teaching English is associated with the following significant functions:

In accordance with the functions carried out by modern technical means, the following ways of using them in the learning process are distinguished:

1. Source of educational information in English. The multimedia technologies used in the modern educational process help to find the necessary didactic information without much effort and time.

2. A tool for choosing didactic information in English and its high-quality processing. The choice of information is largely determined by media selectivity, formed by students' critical thinking, I.E., depends on the level of development of his media culture of the individual.

3. Means of presentation (presentation) of educational material in English. Audiovisual means of a new generation are distinguished by high quality of image and sound, a combination of various channels of information presentation, which contributes to an increase in the efficiency of perception of educational material and, accordingly, leads to better assimilation.

4. A means of exercising control over the implementation of the educational task. Today there are many electronic tests, simulators, training programs that help to control educational activities and evaluate its results.

Multimedia technologies provide such a presentation of information in which a person perceives it with several senses at once in parallel, and not sequentially, as is done in ordinary learning. With the combined impact on the student through sight and hearing, and his involvement in active actions, the share of mastering the educational material can be $75 \%$. 
The use of media in the educational process contributes to the practical implementation of a personality-oriented learning model due to the fact that it creates conditions for greater individualization and differentiation of activities than with the traditional approach, presupposes personal activity, opens up space for self-realization, self-improvement, self-study, self-education, development of creative thinking...

The increased productivity of computers has made possible the widespread use of multimedia technologies in education. A wide range of images, the active inclusion of imaginative thinking in the educational process help the student to perceive the proposed material holistically. The teacher has the opportunity to combine the presentation of theoretical information with the demonstration of demonstration material.

Multimedia computers allow you to reproduce sound (music, speech, etc.), as well as video information (videos, animation films, etc.). Video effects can be represented by showing replaceable computer slides, cartoons, video clips, moving images and texts, changing the color and scale of the image, flickering and fading, etc.

In multimedia programs, a certain way of transmitting information in English is used:

- interaction of various information blocks (text, graphics, video fragments) through hyperlinks. Hyperlinks are presented in the form of specially designed text, or in the form of a specific graphic image. Several hyperlinks can be located on the screen at the same time, and each of them defines its own route;

- interactivity, that is, the dialog mode of the user with the source, in which he can independently choose the information of interest to him, the speed and the sequence of its transmission.

Such a combination leads to the use of various technical devices for recording and reproducing information that can be controlled from a computer by a TV, VCR, HiFi-audio system, compact disc (CD) player, tape recorder and electronic musical instruments.

Educational multimedia programs are used for frontal, group and individual classroom teaching, as well as for independent work at home. They offer a lot of options for individual customization for the user: the student, mastering the educational material, himself sets the speed of study, the volume of the material and the degree of its difficulty.

The knowledge gained remains in memory for a longer period and later it is easier to recover for practical application after repetition.

Teaching English is a complex process, it involves, first of all, the activities of the teacher and the activities of students. In modern conditions, it is necessary to pay great attention to the development of students' creative abilities, their cognitive needs and interests. Teaching as a guide involves the presentation, communication by the teacher of certain knowledge and the management of the process of their mastery by all students in the class. Therefore, the teacher not only presents information on his subject, but also plans, organizes and monitors the student's educational activities, develops the skills of educational work, thinking, ability, the ability to apply knowledge in practice in English.

A special place in solving these problems belongs to the methods and techniques of teaching, which every teacher should be able to correctly use. Without methods and techniques, it is impossible to achieve the set goal, implement the intended content, and fill learning with cognitive activities.

English teacher and methodologist Harold Palmer believed that the main goal of teaching a foreign language was the mastery of oral speech. His method is called the oral method. 
Of greatest interest in the Palmer method is the system of exercises for creating the correct skills of oral speech, which is divided into the following types: purely receptive work (subconscious understanding, conscious oral assimilation, training in following orders, monosyllabic answers to general questions); receptive-imitative work (repetition of sounds, words and sentences after the teacher); conditional conversation (questions and answers, orders and answers, ending sentences); natural conversation.

The audiovisual, or structurally global, method was developed by the scientific and methodological center at the Pedagogical Institute in Saint-Cloud and the Institute of Phonetics in Zagreb. A group of scientists led by famous linguists P. Rivan (France) and P. Guberina (Yugoslavia), creatively applying the provisions of American structuralism and J. Guguenim's work to the syntax of the French language, created an oral method of teaching French to foreigners. The method is designed for adults who need knowledge of the French language for hearing lectures in educational institutions in France and for business communication with the French. This method has also found widespread use in England, Canada, Turkey, Mexico, Poland. It is mainly used in foreign language courses. The language is studied using this method for 3-3.5 months with 20 hours of lessons per week (the entire course of study is 250-300 hours). The ultimate goal is to use a foreign language as a means of communication in the sowing life.

The most rational in the audiovisual method are the methods of developing auditory perception and auditory memory, active working out of strictly selected models, training intonational speech patterns.

The disadvantages of the audiovisual method are: the lack of an accurate understanding of the studied linguistic facts among students and the resulting difficulties in operating them; the fragility of mechanical associations and the destruction of stereotypes with insufficient practice and interruptions in work; underestimation of reading and writing; narrowly practical focus of work, and the lack of general educational elements.

Conclusion: The audiolingual method of teaching foreign languages is based on a behavioral approach to teaching and structural direction in linguistics. The essence of the method is that language is interpreted as "behavior" that should be taught. In accordance with this method, the language should be presented in the form of small in volume and graded in difficulty units, structures that students master by repetition, substitution, transformation, etc. The role of the teacher is to ensure the consolidation of the studied units in the classroom and at home. The teacher must correct all mistakes in order to exclude their repetition in the future and to ensure the correctness of speech.

It is quite obvious that the audiolingual method has a number of disadvantages, the main ones of which are: passivity of learners, lack of initiative on the part of the teacher, training of the language form without relying on the meaning of the studied phenomenon, as well as underestimation of cognitive learning processes and the role of written speech.

\section{REFERENCES:}

1. Турсунов С.Қ. Таълимда электрон ахборот ресурсларини яратиш ва уларни жорий қилишнинг методик асослари (педагогика олий таълим муассасалари “Web-дизайн” фани мисолида). пед. фан. номз...дисс. - Тошкент, 2011. - Б. 138.

2. Тўрақулов O.X. Ахборотлаштирилган таълим мухитида кичик мутахассислар тайёрлашнинг илмий-методик таъминотини такомиллаштириш. Педагогика фанлари буйича докторлик (DSc) диссертацияси автореферати. - Т. 2017. 
3. Усов Ю.Н. Кинообразование как средство эстетического воспитания и художественного развития школьников. Дисс. ... д-ра пед. наук. - М., 1989. - С. 356.

4. Усов Ю.Н. Медиаобразование. Программа для студентов 10-11 класса общеобразовательной школы // Основы экранной культуры. Цикл программ / Рук. Ю.Н. Усов. - М., 1998.

5. Уэллс У. и др. Реклама: принципы и практика. - СПб.: Питер, 2001. - С. 800.

6. Фатеева И.А. Медиаобразование: теоретические основы и опыт реализации. - Челябинск: Изд-го Челяб. гос. ун-та, 2007. - С. 270.

7. Федоров А.В. Развитие медиакомпетентности и критического мышления студентов педагогических вузов. М.: 2007. - С. 615. 